\title{
浅议建筑管理施工管理及其优化
}

\author{
刘海洋 \\ 浙江处州建设管理有限公司 \\ DOI:10.18686/bd.v2i10.1768
}

[摘要] 经济以及技术的发展为我国建筑行业带来了新的发展机遇和挑战, 建筑企业为了更好的立足于现今发展环境 下, 需要对原有的施工管理模式进行不断的优化和创新工作, 提升管理工作的水平, 从而促进企业竞争优势的发展。不过目 前我国建筑企业施工管理中还存在着很多的不足之处, 需要相关人员通过深入的研究制定合理的优化方案, 以保证管理工 作的有效开展。

[关键词] 建筑企业;施工管理;优化方案

建筑企业的施工管理是一项比较繁杂、涉及内容以及 部门较多的工作, 只有制定健全的管理体系, 才可以实现各 部门之间的共同发展。为此,在进行施工管理工作时, 要结 合现今发展的趋势, 对传统的管理模式进行不断的优化和 改革,同时还要找出在管理过程中存在的问题,并提出合理 的解决方案, 保证管理工作实效性的发挥, 促进企业的进一 步发展。

\section{1 建筑施工管理中的主要问题分析}

1.1 安全管理制度不完善

由于施工管理工作涉及的内容比较繁杂, 所以很多的 建筑企业在管理过程中, 对安全管理的重视力度不强, 也没 有制定严格的安全管理制度, 进而大大的降低安全管理工 作的实效性,使得施工过程中问题频生, 增加了工程建设的 危险系数。同时由于安全管理意识的淡薄,很难发现在施工 过程中存在的安全隐患,这也会影响工程建设的整体质量。 另外, 施工人员自身安全意识较弱, 未按照工程建设的相关 标准进行具体的操作, 从而导致管理水平降低, 对施工质量 构成严重的威胁。

\section{2 施工方案执行力度不佳}

施工方案的制定是进行工程建设的基础，是确保工程 有序进行的重要支柱。不过目前在施工过程中, 很多的施工 人员并未按照施工方案的相关要求进行合理的操作, 增加 了管理工作的难度,最终影响工程建设的整体质量。另外, 在施工过程中, 由于一些施工人员自身专业素质的缺失, 技 术能力不达标等情况, 导致工程各个环节缺乏合理性, 从而 影响施工的整体质量, 导致管理功效的大打折扣。

1.3 施工材料以及设备管理能力较低

施工技术的合理应用是实现工程建设标准的重要措 施, 不过在现今的工程建设中,一旦出现技术问题, 相关人 员仅仅是调整技术的使用规范和标准, 却对影响技术水平 的材料以及设备的使用情况置之不理, 这就导致施工过程 中成本的增加, 施工质量也与原有的设计标准相背离, 从而 导致工期的延后,影响其正常使用。

2 影响建筑施工管理工作开展的环境因素
影响施工管理工作开展的环境因素主要分为两方面: 一是自然环境。二是社会环境。

(1)自然环境主要是指施工现场的地质特性、气候、周边 环境以及天气等因素。如果在工程建设中,出现天气变化不 稳定等情况, 久会对施工中混凝土的质量以及浇筑工作带 来严重的影响,如果天气变化情况较大,甚至还会造成工程 的停工, 导致工期延误, 影响工程建设的成本。另外, 施工现 场的地质情况以及干湿度也会对施工材料的质量以及功能 造成一定的损害,进而导致材料的质量出现问题,影响工程 建设的实际质量。除此之外, 施工过程中, 排放的废水以及 废弃垃圾, 也会对周边人们的生活环境以及身体健康构成 严重威胁,并同时影响工程建设的顺利开展。

(2)社会因素主要是指工程建设中相关规范制度的制定 和实施工作。管理制度是提升建筑行业施工效率, 保证建设 质量的重要依据, 企业会对建筑行业的快速发展而做出相 应的改变。不过目前由于我国建筑工程管理内容比较老旧, 并未结合社会发展的趋势进行及时的更新和优化, 使得施 工中新技术以及新工艺的使用缺乏及时性和合理性, 进而 对建筑行业的发展带来了一定的阻碍。再加上, 很多的建筑 企业在施工中并未制定合理的管理制度，直接导致管理工 作比较松散,管理工作不到位等情况的发生, 这也大大的降 低了施工管理工作的效果。

\section{3 提升施工管理水平的具体措施}

3.1 加强对施工过程中各环节的管理力度

为了保证工程建设的顺利开展, 就需要对施工的质量、 进度以及更改事项的内容进行严格的管理, 并结合企业以 及现场的具体情况, 制定合理的施工方案, 对施工中可能存 在的影响因素进行合理的管控, 从而提升工程建设的效率。 另外, 还要对施工人员进行定期的培训, 加强对施工各环节 的监督和管控力度, 保证各环节的使用质量, 促进后期工序 的合理进行。

其次,要对施工中存在的问题进行及时的发现和解决, 并对其解决的效果进行严格的测评, 以免影响后期工作的 开展。同时还要对施工中问题产生的原因进行审查, 针对问 
题及时的加以制止，避免类似情况的再度发生影响施工的 质量。

最后, 还要加强管理人员与工程建设各部门之间的沟 通和协作能力, 提升管理工作的力度和水平, 对施工中存在 的不规范行为进行批评和教育, 从而提升员工的综合素质 能力。同时还要将管理制度落实到人员头上, 使其按照相应 规章制度进行标准化的施工操作，充分的发挥管理工作的 重要功效。

3.2 制定完善的安全管理体系

为了提升施工管理工作的质量和效率，在实际的施工 作业中,要建立健全的安全管理体系,并将制度规范进行有 效的落实和实施,使员工明确安全管理工作的重要性,减少 事故发生的概率,保证施工的安全。另外,建筑企业还应建 立专门的安全管理小组, 对施工的安全情况进行严格的检 查, 保证安全管理工作的落实效率。除此之外, 还要对施工 人员进行定期安全意识培训, 提升员工的安全认知能力, 将 安全建设作为工程的核心内容, 从而有效的开展工程建设。

3.3 加强施工质量管理的力度

质量一直一来都是工程建设中重点关注的内容, 质量 的好坏将直接决定工程后期功效的发挥以及企业经济效益 的增长, 所以在实际的施工中, 要制定严格的质量管理制 度,提升建筑的使用寿命。

首先, 在施工之前做好工序安排, 让施工人员重视技术 质量交底工作，同时对施工过程中所存在的每一个环节都 进行适当的规范, 以此来确保各个环节的施工质量, 并且还 需要针对建筑质量通病采取适当的防治措施, 以此来避免 事故发生的可能性。

其次,在质量管理工作中,完善监督制度的制定,实现 对施工中各个环节的合理监控, 及时的发现施工中存在的 问题, 并提供合理的解决措施, 保证工程建设的质量, 提升 施工的安全。

3.4 加强施工材料质量检测工作

对此环节进行管理时，首先要明确工程建设中材料的 种类和性能,从而选择良好的供应商进行材料的供应,保证 材料的质量, 同时在选购过程中, 要对材料的成本支出进行 合理的管控, 以免出现浪费的现象; 此外, 对进场材料进行 质量检测, 保证其与实际施工需求相符合, 并对施工中使用
的材料进行科学的管理, 最大程度的避免或是减少施工材 料的浪费。

3.5 对施工进度进行合理的优化和管控

在进行施工进度的优化和管理时, 首先需要结合工程 建设的具体要求时间制定合理的施工方案, 并要求施工人 员在保证工程质量的前提下，严格按照方案的相关规定进 行施工, 然后再对每个季度、每个月、每周的施工内容进行 合理的编排, 以此来逐步的将工程进行落实, 这样就能保障 施工进度的合理性, 确保工程能在施工工期内完成, 并最终 实现对施工管理的优化。

3.6 提升成本管控效果

成本管控工作是在保证工程质量的基础上，降低资金 的过度消耗, 提升企业经济效益。为确保成本管控工作功效 的合理发挥,应现结合施工的实际情况, 以及可能影响施工 的因素进行综合且细致的分析，从而制定合理的施工方案， 对其中涉及的材料、技术以及周期进行明确的标明和控制, 要在保证质量的前提下,降低成本的过度消耗, 提升资金的 利用率。

另外, 还要加强施工人员的综合素质能力, 避免出现材 料的过度浪费,增大成本的支出, 同时还应对施工设备进行 定期的维护, 减少设备维修的概率。除此之外, 还要加强各 项目成本核算工作的准确性，从而实现资金的合理规划配 置。

\section{4 结论}

总而言之, 建筑施工管理工作是一项较为复杂的内容, 不过其对工程建设的质量、效率、安全以及资金的合理规划 都有着重要的作用,故而建筑企业应结合实际施工的情况， 制定科学合理的管理方式, 提升管理工作的水平, 进而为保 证企业的长久发展提供有力的支持。

\section{[参考文献]}

[1]刘绍成. 建筑工程施工现场管理的重要性及措施 [J].建材与装饰,2017(19):205.

[2]纪凯,韩瑞祖,姜华.建筑工程施工现场管理存在的问 题及解决方法 [J].科技创新与应用,2016(35):273.

[3]孙焕胜,王静蕾.试论建筑工程的施工现场管理 [J]. 绿色环保建材,2017(05):178. 